\title{
Magnetic behavior of $\mathrm{Bi}_{5} \mathrm{Nb}_{3-3 x} \mathrm{Fe}_{3 x} \mathrm{O}_{15-\delta}$ solid solutions

\author{
N. A. Zhuk ${ }^{1, \dagger}$, N. V. Chezhina ${ }^{2}$, V. A. Belyy ${ }^{3}$, B. A. Makeev ${ }^{4}$, L. V. Rychkova ${ }^{1}$ \\ †nzhuck@mail.ru
}

\author{
${ }^{1}$ Syktyvkar State University, Oktjabrskij pr., 55, Syktyvkar, 167001, Russia \\ ${ }^{2}$ St. Petersburg State University, Universitetsky pr., 26, St. Petersburg, 198504, Russia \\ ${ }^{3}$ Institute of Chemistry of the Komi Science Center of Ural Branch of RAS, Pervomaiskaya st., 48, Syktyvkar, 167982, Russia \\ ${ }^{4}$ Institute of Geology of the Komi Science Center of Ural Branch of RAS, Pervomaiskaya st., 54, Syktyvkar, 167982, Russia
}

Most bismuth compounds with layered perovskite-like structure, analogs of Aurivillius phases, exhibit ferroelectric properties and are of interest from both practical and theoretical points of view. In this study, we carried out magnetochemical measurements of an electronic state and exchange interactions between iron atoms in the solid solutions $\mathrm{Bi}_{5} \mathrm{Nb}_{3} \mathrm{O}_{15}$, obtained by heterovalent substitution of niobium by atoms of iron (III). The iron-containing solid solutions were obtained in a narrow concentration range at $x \leq 0.06$. The iron-containing solid solutions at concentrations $x>0.005$ are characterized by monoclinic distortion of the tetragonal cell $(\mathrm{P} 2 / \mathrm{m})$. The measurements of magnetic susceptibility of the solid solutions were carried out by the Faraday method in the temperature range of $77-400 \mathrm{~K}$. The isotherms of a paramagnetic component of magnetic susceptibility of iron atoms are typical of antiferromagnets. The effective magnetic moment of single iron atoms increases with increasing temperature from $6.87 \mathrm{mB}(90 \mathrm{~K})$ to $6.92 \mathrm{mB}(320 \mathrm{~K})$. The study of the iron-containing $\mathrm{Bi}_{5} \mathrm{Nb}_{3} \mathrm{O}_{15}$ solid solutions has shown that, in the solid solutions iron (III) atoms aggregate to form dimers and tetramers with antiferromagnetic and ferromagnetic types of exchange. The values of antiferromagnetic and ferromagnetic exchange in dimers, $J_{d i m}=-60 \mathrm{~cm}^{-1}$ and $J_{\text {dim }}=40 \mathrm{~cm}^{-1}$, and tetramers, $J_{\text {tetr }}=-40 \mathrm{~cm}^{-1}$ and $J_{\text {tetr }}=25 \mathrm{~cm}^{-1}$ correspondently.

Keywords: magnetic susceptibility, exchange interactions, distribution of iron atoms.

\section{Introduction}

Most bismuth compounds with layered perovskite-like structure, analogs of Aurivillius phases, exhibit ferroelectric properties and are of interest from both practical and theoretical points of view [1-7]. The composition of these compounds is described by the general formula $\left(\mathrm{Bi}_{2} \mathrm{O}_{2}\right)\left(\mathrm{A}_{n-1} \mathrm{~B}_{n} \mathrm{O}_{3 n+1}\right)$, where $\mathrm{Bi}_{2} \mathrm{O}_{2}$ are bismuth-oxygen layers formed by pyramids of $\mathrm{BiO}_{4}$ and joined to each other by base edges, while $\mathrm{A}_{n-1} \mathrm{~B}_{n} \mathrm{O}_{3 n+1}$ are perovskite-like fragments consisting of corner-connected $\mathrm{BO}_{6}$ octahedra, with large cations $\mathrm{A}$ in the octahedral holes. The coefficient $\mathrm{n}$ in this formula corresponds to the number of $\mathrm{BO}_{6}$ octahedra in the thickness of perovskite-like fragments and can vary from 1 to $5[1-3]$. Previously it was found that along with the aforementioned usual layered compounds with invariable perovskite-like fragments, the so-called mixedor hybrid-layered compounds, $\left(\mathrm{Bi}_{2} \mathrm{O}_{2}\right)\left(\mathrm{A}_{n-1} \mathrm{~B}_{n} \mathrm{O}_{3 n+1}\right) \ldots$ $\left(\mathrm{Bi}_{2} \mathrm{O}_{2}\right)\left(\mathrm{A}_{m-1} \mathrm{~B}_{m} \mathrm{O}_{3 m+1}\right)$, can also exist, which have perovskitelike fragments with various thicknesses [8-10]. Bismuth niobate, $\mathrm{Bi}_{5} \mathrm{Nb}_{3} \mathrm{O}_{15}$, has mixed-layered structure with orderly variation of fragments with one and two niobium-oxygen octahedra thickness (Fig. 1).

Its structure can be described as $\left(\mathrm{Bi}_{2} \mathrm{O}_{2}\right)\left(\mathrm{NbO}_{4}\right)\left(\mathrm{Bi}_{2} \mathrm{O}_{2}\right)$ $\left(\mathrm{BiNb}_{2} \mathrm{O}_{7}\right)$, when $n=1$ and $m=3$. The oxygen-niobium octahedra connected to each other by side corners are located in the crystallographic ab-plane; the bond angle between $\mathrm{Nb}-\mathrm{O}-\mathrm{Nb}$ atoms is $180^{\circ}$. The layers of octahedra are separated by bismuth-oxygen layers $\mathrm{Bi}_{2} \mathrm{O}_{2}$, consisting of $\mathrm{BiO}_{4}$ pyramids and joined to each other by base edges. Previous studies of magnetic dilution of solid solutions $\mathrm{Bi}_{5} \mathrm{Nb}_{3-3 x} \mathrm{M}_{3 x} \mathrm{O}_{15-\delta}$ $(\mathrm{M}-\mathrm{Cr}, \mathrm{Ni}, \mathrm{Cu})$ gave reason to suppose that the heterovalent substitution of niobium by atoms of lower valence in the dilute solid solutions is accompanied by partial oxidation of the paramagnetic atoms. Whereas in the concentrated solutions, the structure is stabilized by formation of clusters of paramagnetic atoms localized near the oxygen vacancies [11-13]. The character and energy of the interatomic interaction in the exchange-interactioning clusters are determined by the nature of atoms of paramagnetic materials. The values of the exchange parameter for paramagnetic atoms in the solid solutions $\mathrm{Bi}_{5} \mathrm{Nb}_{3} \mathrm{O}_{15}$ obey the regularity, an increase in values of the exchange parameter from chromium to copper atoms, which is associated with spatial arrangement of corresponding $d$-orbitals and a number of electrons of 3d-elements participating in the indirect exchange interactions.

In this study, we carried out magnetochemical measurements of an electronic state and exchange interactions between iron atoms in the solid solutions $\mathrm{Bi}_{5} \mathrm{Nb}_{3} \mathrm{O}_{15}$, obtained by heterovalent substitution of niobium by atoms of iron (III). 


\section{Experimental details}

Synthesis of the samples of solid solutions was carried out via the standard ceramic method from oxides of bismuth (III), $\mathrm{Nb}(\mathrm{V})$ and iron (III), purissimum speciale grade, at the temperatures of $750^{\circ} \mathrm{C}$ and $1050^{\circ} \mathrm{C}$. The phase composition of the samples was controlled by scanning electron microscopy (Tescan Vega-3) and X-ray diffraction (DRON-4-13, $\mathrm{Cu}_{\mathrm{K} \alpha}{ }^{-}$ radiation), unit cell parameters of the solid solutions were calculated using the CSD program package [14]. Quantitative determination of iron content in the samples was carried out with atomic emission spectrometry (an inductively coupled plasma mass spectrometer SPECTRO CIROS) with an accuracy of $5 \%$ of the index $x$ in a solid solution formula. Melting temperatures of solid solutions were determined by differential scanning calorimetry (Netzsch STA 409 PC Luxx, the Centre of collective use "Himiya" of the Institute of chemistry of Komi SC UB RAS) in platinum-rhodium crucibles at a heating rate of $10 \mathrm{~K} / \mathrm{min}$. The measurements of magnetic susceptibility of the solid solutions were carried out by the Faraday method in the temperature range of $77-400 \mathrm{~K}$, with 16 fixed temperature values. The accuracy of the relative measurements was $2 \%$.

\section{Results and discussion}

The iron-containing solid solutions were obtained in a narrow concentration range at $x \leq 0.06$. Single-phase structure of the derived samples was confirmed by X-ray diffraction and electron microprobe analysis (Fig. 2, 3).

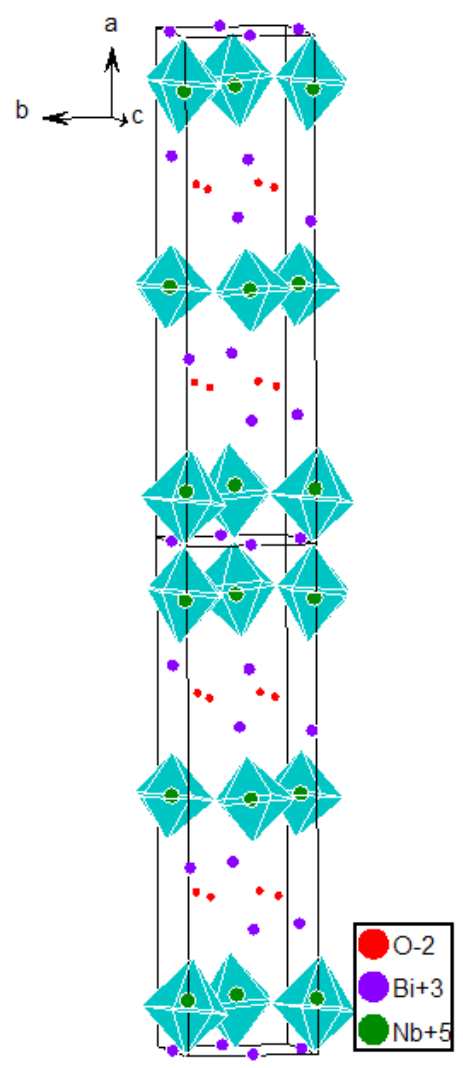

Fig. 1. (Color online) Crystal structure of bismuth niobate, $\mathrm{Bi}_{5} \mathrm{Nb}_{3} \mathrm{O}_{15}$.

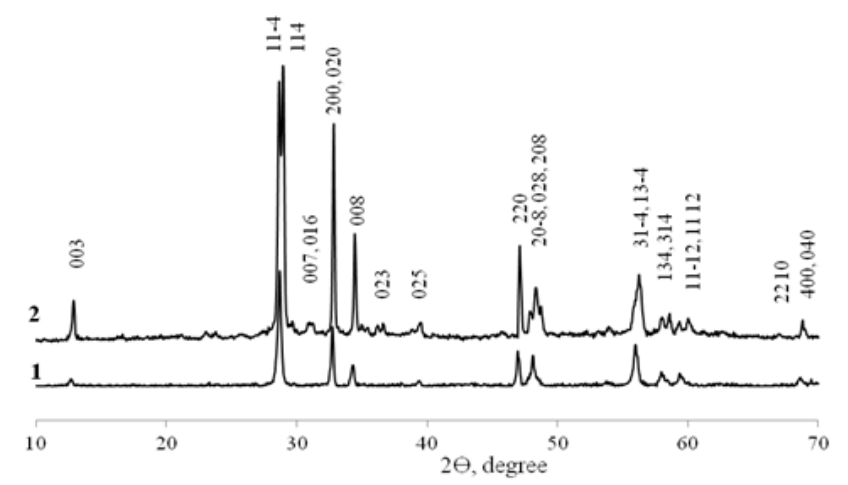

Fig. 2. The XRD pattern of $\mathrm{Bi}_{5} \mathrm{Nb}_{3} \mathrm{O}_{15}$ (1) and $\mathrm{Bi}_{5} \mathrm{Nb}_{1.82} \mathrm{Fe}_{0.18} \mathrm{O}_{9-\delta}$ (2).

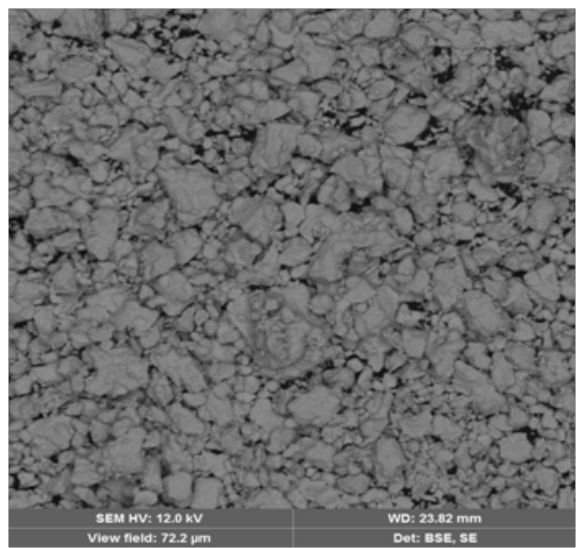

a
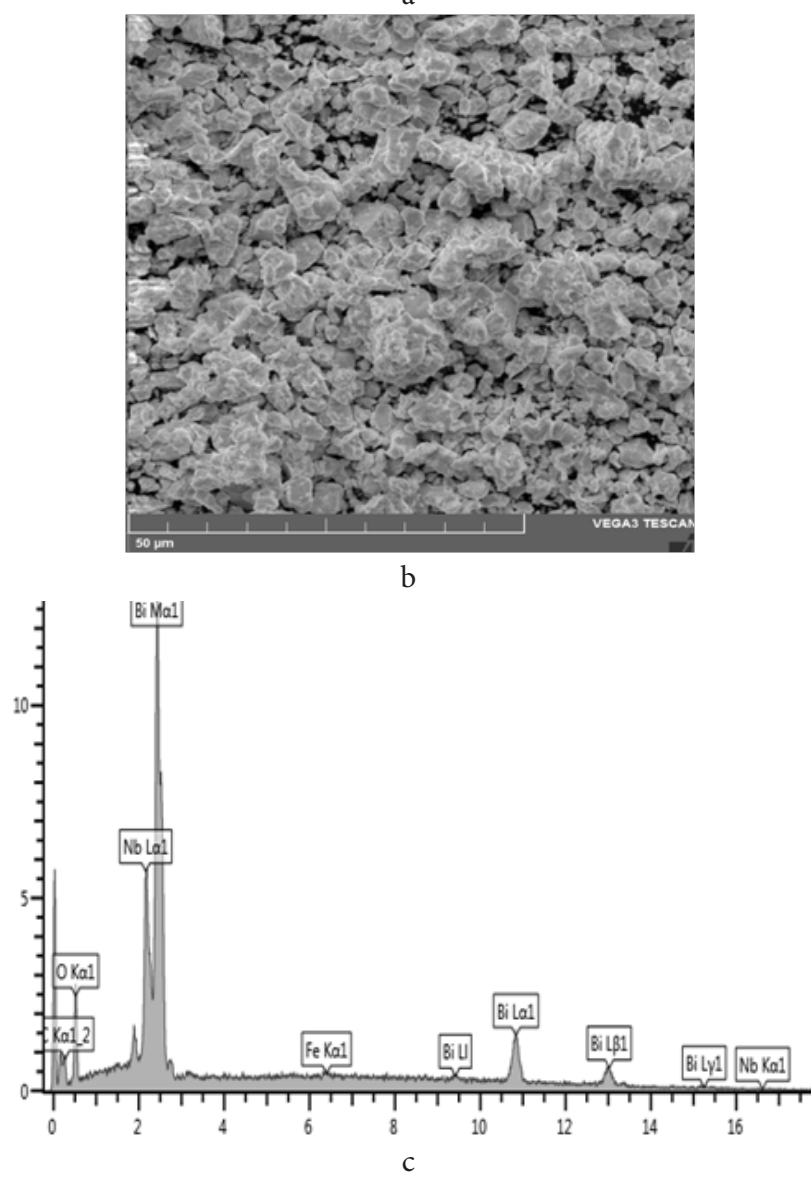

Fig. 3 The SEM micrograph (a, b) and the EDX-spectrum (c) $\mathrm{Bi}_{5} \mathrm{Nb}_{1.82} \mathrm{Fe}_{0.18} \mathrm{O}_{9-\delta}$. 
The iron-containing solid solutions at concentrations $x>0.005$ are characterized by monoclinic distortion of the tetragonal cell, which is manifested by a deviation of angle $\boldsymbol{a}$ from $90^{\circ}$ and by non-equivalence of the parameters $\boldsymbol{a}$ and $\boldsymbol{b}$.

The roentgenograms of the solid solutions at $x \leq 0.06$ were interpreted assuming space group $\mathrm{P} 2 / m[15,16]$. The increase of content of iron atoms leads to decrease of the elementary lattice parameter $\boldsymbol{a}$ to $0.5457 \mathrm{~nm}$, increase of $\boldsymbol{b}$ and $\boldsymbol{c}$ to 0.5462 and $2.091 \mathrm{~nm}$, respectively, and alteration of a angle from $90^{\circ}$ to $90.8^{\circ}(x=0.06)$. Monoclinic distortion of the tetragonal cell of the solid solutions $\mathrm{Bi}_{5} \mathrm{Nb}_{3} \mathrm{O}_{15}$ associated with formation of atomic defects in the structure was established earlier in [11-13]. Melting temperatures of $\mathrm{Bi}_{5} \mathrm{Nb}_{3} \mathrm{O}_{15}$ and $\mathrm{Bi}_{5} \mathrm{Nb}_{3-3 x} \mathrm{Fe}_{3 x} \mathrm{O}_{15-\delta}(x=0.06)$ determined by differential scanning calorimetry were $1188^{\circ} \mathrm{C}$ and $1180^{\circ} \mathrm{C}$, respectively. Measurements of magnetic susceptibility of the solid solutions allowed calculating a paramagnetic component of the magnetic susceptibility $\left[\chi^{\text {para }}(\mathrm{Fe})\right]$ and the values of effective magnetic moments $\left[\mu_{e f}(\mathrm{Fe})\right]$ of iron atoms for different temperatures and for different concentrations of the paramagnetic component.

The isotherms of a paramagnetic component of magnetic susceptibility of iron atoms are typical of antiferromagnets as shown in Fig. 4. The effective magnetic moment of single iron atoms, calculated by extrapolation of the concentration dependence of $\left[\chi^{\text {para }}(\mathrm{Fe})\right]$ to infinite dilution of solid solutions, increases with increasing temperature from $6.87 \mathrm{mB}(90 \mathrm{~K})$ to $6.92 \mathrm{mB}(320 \mathrm{~K})$. It should be considered that the increase in the magnetic moment of the atoms of iron (III) relative to the pure spin values of Fe (III) $\left(\mu_{e f}=5.92 \mathrm{mB}\right.$, term $\left.{ }^{6} \mathrm{~A}_{\mathrm{lg}}\right)$ and $\mathrm{Fe}$ (II) atoms $\left(\mu_{e f}=4.9 \mathrm{mB},{ }^{5} \mathrm{~T}_{2 \mathrm{~g}}\right)$ cannot be caused by the spin-orbit interaction or zero-field effects. Therefore, it remains to assume that the exchange interactions of the ferromagnetic type take place in the highly diluted solutions with layered structure. The decrease of the paramagnetic component of magnetic susceptibility of the atoms with increasing concentrations of solid solutions associated with antiferromagnetic interactions between iron atoms. This assumption is confirmed by the temperature dependence of the effective magnetic moment of iron atoms in the solid

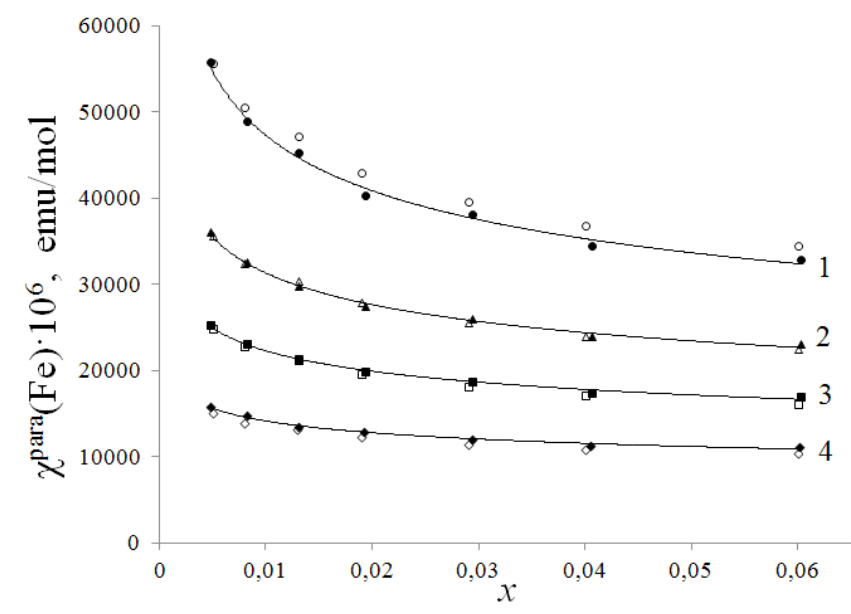

Fig. 4. The comparison of the theoretical and experimental values of magnetic susceptibility of the solid solutions at $90 \mathrm{~K}$ (1), $140 \mathrm{~K}(2)$, $200 \mathrm{~K}(3)$ and $320 \mathrm{~K}(4)$. solutions with different concentrations of paramagnetic atoms. Simulation of the solid solutions composition depending on the content of the paramagnetic substance required a theoretical calculation of the susceptibility and comparison of the results obtained with the experimental values. The calculation of the concentration dependencies of $\chi^{\text {para }}(\mathrm{Fe})$ of the solid solutions was carried out within the framework of the model of dilute solid solution, where the magnetic susceptibility is defined as a sum of contributions from individual paramagnetic atoms and their exchangeinteractioning clusters. The formula for calculating the paramagnetic component of magnetic susceptibility of iron atoms is a sum of contributions of magnetic susceptibility of dimers and tetramers with antiferromagnetic and ferromagnetic types of interaction (1):

$$
\begin{aligned}
& \chi_{\text {calc }}^{\text {para }}(\mathrm{Fe})=\left(1-a_{\mathrm{Fe}(\mathrm{III})}^{\operatorname{dim}(f)}-a_{\mathrm{Fe}(\mathrm{III})}^{\operatorname{dim}(a)}-a_{\mathrm{Fe}(\mathrm{III})}^{\operatorname{tetr}(a)}\right) \chi_{\mathrm{Fe}(\mathrm{III})}^{\operatorname{tetr}(f)}+ \\
& +a_{\mathrm{Fe}(\mathrm{III})}^{\operatorname{dim}(f)} \chi_{\mathrm{Fe}(\mathrm{III})}^{\operatorname{dim}(f)}+a_{\mathrm{Fe}(\mathrm{III})}^{\operatorname{dim}(a)} \chi_{\mathrm{Fe}(\mathrm{III})}^{\operatorname{dim}(a)}+a_{\mathrm{Fe}(\mathrm{III})}^{\operatorname{tet}(a)} \chi_{\mathrm{Fe}(\mathrm{III})}^{\operatorname{tetr}(a)},
\end{aligned}
$$

where, $a_{\mathrm{Fe}(\mathrm{III})}^{\operatorname{dim}(f)}, a_{\mathrm{Fe}(\mathrm{III})}^{\operatorname{dim}(a)}$ and $a_{\mathrm{Fe}(\mathrm{III})}^{\text {tetr }(a)}$ are proportions of dimers and tetramers of $\mathrm{Fe}$ (III) atoms with ferro- and antiferromagnetic types of interactions, $\chi_{\mathrm{Fe}(\mathrm{III})}^{\operatorname{dim}(f)}, \chi_{\mathrm{Fe}(\mathrm{III})}^{\operatorname{dim}(a)}, \chi_{\mathrm{Fe}(\mathrm{III})}^{\operatorname{tetr}(f)}$ and $\chi_{\mathrm{Fe}(\mathrm{III})}^{\operatorname{tet}(a)}$ are the magnetic susceptibilities of dimers and tetramers with ferroand antiferromagnetic exchange.

The formula (1) comprises seven independent parameters: the proportion of dimers and tetramers with different type of exchange, and implicit parameters of antiferromagnetic exchange between atoms of iron (III) in the dimers and tetramers. According to the Heisenberg-Dirac-van Vleck model [17]: magnetic susceptibility of tetramers consisting of paramagnetic atoms can be calculated using the formula (2):

$\chi_{\text {tetr }}^{S_{1}-S_{2}}=\frac{1}{4} \frac{\sum_{S^{\prime}} \sum_{S_{12}} \sum_{S_{34}} g^{2}\left(S^{\prime}\right) S^{\prime}\left(S^{\prime}+1\right)\left(2 S^{\prime}+1\right) e^{-E\left(J, S^{\prime}\right) / k T}}{8 T \sum_{S^{\prime}} \sum_{S_{12}} \sum_{34}\left(2 S^{\prime}+1\right) e^{-E\left(J, S^{\prime}\right) / k T}}$,

where $\quad E\left(J, S^{\prime}\right)=-J\left[S^{\prime}\left(S^{\prime}+1\right)-4 S_{1}\left(S_{1}+1\right)\right], \quad S_{12}=S_{1}+S_{2}$, $S_{1}+S_{2}-1, \ldots,\left|S_{1}-S_{2}\right|, \quad S_{34}=S_{3}+S_{4}, \quad S_{3}+S_{4}-1, \ldots,\left|S_{3}-S_{4}\right|$, $S^{\prime}=S_{12}+S_{34}, S_{12}+S_{34}-1, \ldots,\left|S_{12}-S_{34}\right|$. Here, $S_{1}$ and $S_{2}, S_{3}$ and $S_{4}$ are the values of spins of tetramer atoms, in this case, $S_{1}=S_{2}=S_{3}=S_{4}=5 / 2$ for the tetramer $\mathrm{Fe}(\mathrm{III})-\mathrm{O}-\mathrm{Fe}$ (III)-O$\mathrm{Fe}(\mathrm{III})-\mathrm{O}-\mathrm{Fe}(\mathrm{III}) . S^{\prime}, S_{12}$ and $S_{34}$ are the values of the total spin of the cluster and the intermediate moments, $g$ is the Lande's factor of iron (III) atoms, $J$ is the exchange parameter, $T$ is an absolute temperature.

The calculated and experimental values are approved by minimizing the function $\sum_{i} \sum_{j}\left(\chi_{i j}^{\text {calc }}-\chi_{i j}^{\text {exp }}\right)^{2}$, where $\sum_{i}$ is a summation over all concentrations; $\sum_{j}$ is a summation over all temperature values; $\chi_{i j}^{\text {exp }}, \chi_{i j}^{\text {calc }}$ are experimental and calculated values of a paramagnetic component of magnetic susceptibility of the solid solutions.

The best agreement between the experimental and calculated data for the solid solutions $\mathrm{Bi}_{5} \mathrm{Fe}_{3 x} \mathrm{Nb}_{3(1-x)} \mathrm{O}_{15-\delta}$ was obtained with the values of antiferromagnetic and ferromagnetic exchange in dimers, $J_{d i m}=-60 \mathrm{~cm}^{-1}$ and $J_{\text {dim }}=40 \mathrm{~cm}^{-1}$, and tetramers, $J_{\text {tetr }}=-40 \mathrm{~cm}$ and $J_{\text {tetr }}=25$ $\mathrm{cm}^{-1}$, correspondently. The comparison of the theoretical and experimental values of magnetic susceptibility of the solid solutions is given in Fig. 4. The study of the ironcontaining $\mathrm{Bi}_{5} \mathrm{Nb}_{3} \mathrm{O}_{15}$ solid solutions has shown that, in the 
infinitely dilute solid solution, iron (III) atoms aggregate to form dimers and tetramers with antiferromagnetic and ferromagnetic types of exchange (Fig. 5). Apparently, the formation of aggregates of paramagnetic atoms near the oxygen vacancies results in stabilization of the structure of the solid solutions. The formation of clusters with antiferromagnetic and ferromagnetic types of exchange indirectly indicates that iron (III) atoms belong to crystal fields of different symmetry. There is no doubt in the manifestation of the antiferromagnetic type of exchange in the layered perovskite structure. The antiferromagnetic exchange between paramagnetic iron (III) atoms can occur within a single layer of regular octahedra through the channels $d_{x^{2}-y^{2}}\left\|p_{x}\right\| d_{x^{2}-y^{2}}$ and $d_{x^{2}-y^{2}}\left\|p_{y}\right\| d_{x^{2}-y^{2}}$, and between the layers through the channel $d_{z^{2}}\left\|p_{z}\right\| d_{z^{2}}$. Ferromagnetic exchange between heterovalent atoms is not possible due to the absence of other degrees of oxidation of iron atoms. The assumption about the possibility of the ferromagnetic indirect exchange between Fe (III) atoms at the angle of $180^{\circ}$ in the crystal field of undistorted octahedral symmetry contradicts the theory of magnetic exchange [18]. However, the geometric distortions of lengths and angles of bonds between paramagnetic atoms and the anionic vacancies formed inevitably due to heterovalent substitutions promote the appearance of the ferromagnetic exchange. The existence of these distortions is indirectly indicated by the monoclinic distortion of tetragonal structure of the solid solutions of bismuth niobate associated with the incline of the crystallographic axis $c$ to the plane of perovskite layers. The ferromagnetic exchange has a high probability within the same layer of octahedra in the plane, which is perpendicular to the axis $c$, on the crossexchange channels, $d_{x^{2}-y^{2}} \perp p_{x} \perp d_{x y}$ and $d_{x^{2}-y^{2}}\left\|p_{x} \perp p_{y}\right\| d_{x y}$, for example. As the proportion of clusters with the ferromagnetic type of exchange increases with dilution of solid solutions, it can be assumed that the iron (III) atoms firstly occupy cationic positions within the same layer of octahedron. A single layer of niobium-oxygen octahedra is tolerant to inclusion of heterovalent atoms. This is apparently due to

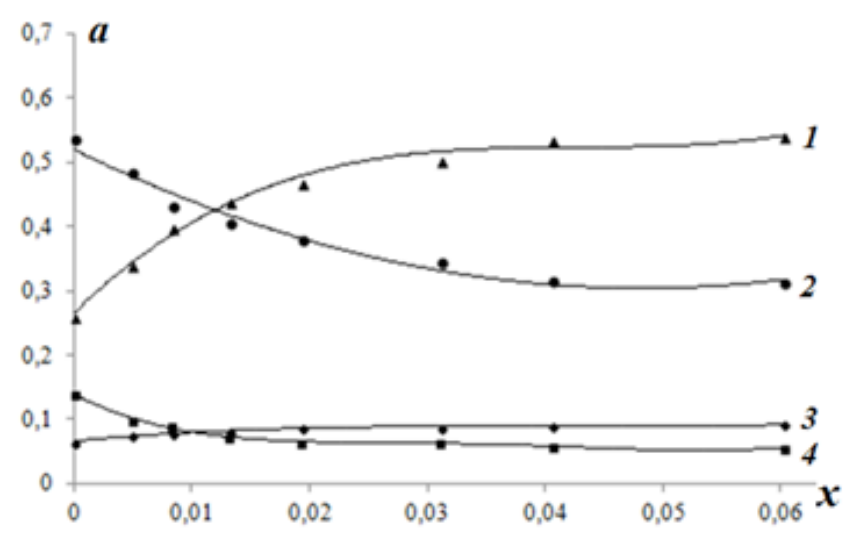

Fig. 5. The dependence of proportion of dimers $a_{\mathrm{Fe}(\mathrm{III})}^{\operatorname{dim}(a)}$ with antiferromagnetic type of exchange (1), dimers $a_{\mathrm{Fe}(\mathrm{III})}^{\operatorname{dim}(f)}$ with ferromagnetic type of exchange (2), tetramers $a_{\mathrm{Fe}(\mathrm{tII})}^{\text {tetr }(a)}$ with antiferromagnetic type of exchange (3), and tetramers $a_{\mathrm{Fe}(\mathrm{tIII})}^{\operatorname{tet}(f)}$ with ferromagnetic type of exchange (4) from the concentration of iron atoms in $\mathrm{Bi}_{5} \mathrm{Nb}_{3-3 x} \mathrm{Fe}_{3 x} \mathrm{O}_{15-\delta}$. the possibility of loss of oxygen atoms occupying the axial positions in the coordination polyhedrons. Partial ordering in cations distribution on different perovskite fragments was noted earlier by the authors [16] in the study of $\mathrm{Bi}_{5} \mathrm{Nb}_{3} \mathrm{O}_{15}-\mathrm{Bi}_{5} \mathrm{Ti}_{1.5} \mathrm{~W}_{1.5} \mathrm{O}_{15}$ system. It was shown that tungsten atoms fill at first the cationic positions in the niobium-oxygen layers which are one octahedron thick. After that, they are statistically distributed in the positions in the fragments with the thickness of two octahedra.

It should be noted that, despite a significant proportion of clusters with the ferromagnetic type of exchange in the infinitely dilute solution (Fig. 4), the exchange, in general, is antiferromagnetic. Apparently, this is because the overlap of orbitals of the atoms involved in the antiferromagnetic exchange is more effective, as well as the structures of solid solutions causing the ferromagnetic exchange have a relatively small geometric distortion. A portion of clusters with ferromagnetic type of exchange decreases with increasing concentration of the solid solutions, due to averaging of local distortions of the structure and formation of aggregates with predominantly antiferromagnetic type of exchange.

\section{Conclusion}

The iron-containing solid solutions were obtained in a narrow concentration range at $x \leq 0.06$. The solid solutions at concentrations $x>0.005$ are characterized by monoclinic distortion of the tetragonal cell. Melting temperatures of $\mathrm{Bi}_{5} \mathrm{Nb}_{3} \mathrm{O}_{15}$ and $\mathrm{Bi}_{5} \mathrm{Nb}_{3-3 x} \mathrm{Fe}_{3 x} \mathrm{O}_{15-\delta}(x=0.06)$ determined by differential scanning calorimetry were $1188^{\circ} \mathrm{C}$ and $1180^{\circ} \mathrm{C}$, respectively. The study of the iron-containing $\mathrm{Bi}_{5} \mathrm{Nb}_{3} \mathrm{O}_{15}$ solid solutions has shown that, in the solid solutions iron (III) atoms aggregate to form dimers and tetramers with antiferromagnetic and ferromagnetic types of exchange.

\section{References}

1. G. A. Smolensky, V.A. Isupov, A.I. Agranovskaya, Sov. Phys.Sol. St., 3, 651 (1961). (in Russian) [Г.А. Смоленский, В.А. Исупов, А.И. Аграновская, Физика твердого тела, 3, 899 (1961).]

2. G. A. Geguzina, A.T. Shuvaev, E.T. Shuvaeva, et al. Cristall. Rep. 50, 52 (2005). (in Russian) [Г. А. Гегузина, А. Т. Шуваев, Е. Т. Шуваева и др, Кристаллография, 50, 59 (2005).] DOI: 10.1134/1.1857245

3. V.A. Isupov, Ferroelectrics, 189, 211 (1996). DOI: 10.1080/00150199608213420.

4. R. Macquart, B. J. Kennedy, T. Kamiyama, F. Izumi, J. Phys.-Condes. Matter. 16, 5443 (2004). DOI: 10.1088/0953-8984/16/30/007.

5. N. V. Chezhina, I. V. Piir, N. A. Zhuk, Rus. J. Gen. Chem., 84, 185 (2014). (in Russian) [Н. В. Чежина, И.В.Пийр, H.А. Жук, ЖОХ, 2, 189 (2014).] DOI: 10.1134/ S1070363214020030

6. N. V. Chezhina, I. V. Piir, N. A. Zhuk, Rus. J. Gen. Chem., 75, 21 (2005). (in Russian) [Н. В. Чежина, И. В. Пийр, H.А. Жук, ЖОХ, 75, 24 (2005).] DOI: 10.1007/ s11176-005-0165-6 
7. N. A. Zhuk, I. V. Piir, Inorgan. Mat., 44, 1362 (2008). (in Russian) [Н. А. Жук, И. В. Пийр, Неорг. матер., 44, 1504 (2008).] DOI: 10.1134/S0020168508120182

8. G. A. Geguzina, A. T. Shuvaev, E. T. Shuvaeva, S. G. Gakh, Cristall. Rep. 48, 359 (2003). (in Russian) [Г.А. Гегузина, А. Т. Шуваев, Е. Т. Шуваева, С. Г. Гах, Кристаллохимия, 48, 403 (2003).] DOI: 10.1134/1.1578114

9. J. Gopalakrishnan, A. Ramanan, C.N. R. Rao, D. A. Jefferson, D. J. Smith. J. Sol. St. Chem, 55,101 (1984). DOI: 10.1016/0022-4596(84)90252-4.

10. T. Takenaka, K. Komura, K. Sakata, Jpn. J. Appl. Phys. 35, 5080 (1996). DOI:10.1143/JJAP.35.5080

11. N. A. Zhuk, I. V. Piir, N. V. Chezhina, Rus. J. Gen. Chem. 78, 376 (2008). (in Russian) [Н.А. Жук, И. В. Пийр, H.В. Чежина, ЖОХ, 78, 393 (2008).] DOI: 10.1134/ S1070363208030079

12. N.A. Zhuk, I.V. Piir, A.L. Pimenov, N.V. Chezhina, Rus. J. Gen. Chem. 78, 335 (2008). (in Russian) [Н. А. Жук, И. В. Пийр, А. Л. Пименов, Н. В. Чежина, ЖОХ, 78, 353 (2008).] DOI: 10.1134/S1070363208030079

13. N.A. Zhuk, I.V. Piir, A.L. Pimenov, N.V. Chezhina. Rus. J. Gen. Chem. 77, 990 (2007). (in Russian) [Н. А. Жук,
И. В. Пийр, А. Л. Пименов, Н. В. Чежина, ЖОХ, 77, 898 (2007).] DOI: 10.1134/S1070363207060059

14. L. G. Akselrud, Yu. N. Gryn, P. Yu. Zavalij, Thes. Rep. 12th Eur. Crystallogr. Meet. 155 (1985).

15. V.K. Yanovskij, V.I. Voronkova, I. N. Leonteva, Inorgan. Mater. 26, 1154 (1990). (in Russian) [В.К. Яновский, В. И. Воронкова, И. В. Водолазская, Неорг. матер., 26, 1297 (1990).]

16. V.K. Yanovskij, V.I. Voronkova, I. N. Leonteva, Inorgan. Mater. 25, 706 (1989). (in Russian) [В.К. Яновский, В.И. Воронкова, И.Н. Леонтьева, Неорг. матер., 25, 834 (1989).]

17. Yu. V. Rakitin. Introduction to magnetochemistry. The method of static magnetic susceptibility in chemistry. Moscow: Science. 302 pp. (1980). (in Russian) [Ю.В. Ракитин, Введение в магнетохимию. Метод статической магнитной восприимчивости в химии. М: Наука. 302 С. (1980).]

18. D. B. Goodenough, Magnetism and the Chemical Bond. Moscow: Metallurgy. 328 pp. (1968). (in Russian) [Д.Б. Гуденаф, Магнетизм и химическая связь. М: Металлургия. 328 С. (1968).] 